\title{
Principal Leadership Strategy in Improving Teacher Performance at SMK Bakti Ibu 3 Palembang
}

\author{
Yellin Agustine ${ }^{1 *}$, Syarwani Ahmad ${ }^{2}$, Alfroki Martha ${ }^{2}$ \\ ${ }^{1}$ SMK Bakti Ibu 3 Palembang \\ ${ }^{2}$ Universitas PGRI Palembang \\ *Corresponding author. Email: Yellin.agustine@gmail.com
}

\begin{abstract}
The purpose of this research is to describe the leadership strategy of the principal innature toimprove the performance of teachers at SMK Bakti Ibu 3 Palembang. By using qualitatively described methods, there have been many strategies of the principal, but there has not been a significant effect of the strategy, so that the teacher's performance has not been able to reach the target. The results showed: The Principal's Leadership Strategy in Improving Teacher Performance, Such as: (1) Planning: By arranging according to the school's vision, mission and objectives; (2) Organizing by dividing the teacher's duties in accordance with their respective fields of knowledge; (3) Implementation by providing guidance to teachers to perform work according to the description of their duties; (4) supervision by controlling existing learning activities and teacher attendance; (5) Evaluation by assessing the work of teachers, for teachers who excel are rewarded and teachers who are weak in performance are given special coaching. Thus, the researchers recommended that if they want the teacher's performance to improve, then improve the strategy of the principal at SMK Bakti Ibu 3 Palembang.
\end{abstract}

Keywords: Strategy, Principal, Teacher Performance

\section{INTRODUCTION}

Education has a very important role in shaping the development and self-realization of individuals, especially for the development of nations and countries. Education makes the most fundamental aspect of the moral determination of a nation, when there is a moral crisis in a nation, it is closely related to the quality of education given to members of society as learners. Therefore, education is a very important element in living life. Because if you look from along the journey of human education is a barometer to achieve maturation of the values of life. Education is a human effort to build his personality in accordance with the values in society and culture. Education can be limited in its narrow and broad sense. In a narrow sense education is a conscious and planned effort to help students mature their maturity [1].

The progress and retreat of education is influenced by management as a driver in the education process, so that in the implementation of education will never be separated from management. Because without management, education becomes unclear in size so it will be difficult to achieve the goals that have been set, both the goals formulated in SISDIKNAS or the goals formulated in the educational institutions itu own and with the management that education will determine the efficiency and effectiveness of an education [2].

The quality of educational institutions is determined by the good and bad quality of management, management that has good skin certainly has a leader who is able to move the institution in accordance with the objectives of the institution that has been planned. According to Rifa'I and Anni [3] said that "Leaders should provide leadership functions including Coordination, Decision Making, Communication, and attention to subordinates. Basically, the behavior of the leader is to give an aberration to subordinates, complete tasks and develop subordinates, pay attention to employees how to do a job, carry out obligations and correct setbacks due to setbacks in achieving goals.

The leadership strategy refers to the attitude, the way the leadership looks. Shulhan [4] said that "Leadershipstrategy is the norm of behavior used by a person when the person tries to influence the behavior of others as he seesit". The headmaster's leadership strategy is a factor related to the productivity and effectiveness of the organization, while productivity and effectiveness will be achieved well if the performance is 
of. Thus, the leadership strategy is a type or style used by a leader that is carried out to influence the activities of others in order for the organization's goals to be achieved.

The headmaster has a demand to have good skills in making every decision that can be used as the basis, strategy, or activity program of the School. The ability of the headmaster to determine quality decisions through systematic measures greatly affects the effectiveness of the school, so that the headmaster's policy will determine the mechanism of the school's work and play a major role in improving the school's quality cultural climate. The ability of the headmaster as an education leader, is required to be able to determine the right strategy or leadership style to provide assistance to teachers to improve their performance. Mistakes in implementing the headmaster's strategy or leadership style will have an impact on the success of improving the performance of teachers in their leadership. This, often happens in the implementation of the process of improving the performance of teachers in schools.

A leader in the school in this case the headmaster and the teacher must know their duties and responsibilities, and the most important thing is how the headmaster is able to practice and make this in the form of actions in the school. When the relationship between the principal and the teacher is well established and between the school resources have known their respective duties and functions, the management system will be easily implemented.

Based on the phenomenon that occurred in the field, namely at SMK Bakti Ibu 3 Palembang, there were some problems in the headmaster's duties as the highest leader in the school that had an impact on the principal's duties that were not carried out optimally, including the difficulties faced by the headmaster in making planning due to the lack of participation from employees and teachers that caused difficulty in determining the decision. Another difficulty is the difference in perspective, habits, willingness and skills of teachers in an effort to unite the vision and mission towards achieving the school's goals. The lack of socialization of schools with the community led to the paradigm of the community positioning teachers as the main key to the success and failure of education in schools.

But behind all the problems above, SMK Bakti Ibu 3 Palembang actually has academic and non-academic achievements that can be proud. The achievements that have been achieved smk Bakti Ibu 3 Palembang is once won in every field of sports exculkul, Scout, PMR, Paskibra and many more in the field of other exculkul. The achievements that have been achieved by the students of SMK Bakti Ibu 3 Palembang will not be separated from the role of teachers in fostering and guiding students so that students at SMK Bakti Ibu 3 Palembang can bring the fragrant name of the school.

From the various exposures described above, it can be seen that leadership is not only needed in institutions that are business only, but all institutions at this time do need management, including in this case in educational institutions that will be the object for this research, namely SMK Bakti Ibu 3 Palembang as a basic educational institution, in which there is a principal as a leader.

Therefore, there are several reasons that encourage the author to do this research, one of which is that progress in the field of education requires a leader who is able to manage the education unit and is able to improve teacher performance in achieving educational goals, and as the paradigm develops in society that has the assumption that the principal in Indonesia has weaknesses in terms of managerial competence and supervision, and furthermore the community has been positioning teachers as the main key to success and failure of education, whereas a teacher is only one component of education in the school, in addition to teachers, the principal is the party that plays a very important role especially in terms of improving teacher performance through his leadership strategy.

\section{METHODS}

This research was conducted at SMK Bakti Ibu 3 Palembang, South Sumatra Province, for 4 months, from October 2020 to January 2020. The type of research used in this research is descriptive with qualitative approach, which is a type of research that seeks to describe a phenomenon in accordance with what is happening in the field, where the data produce written or spoken words from people and observable behavior. The data collected is in the form of words, written documents pictures. In other words, descriptive methods intend to make an objective representation of the symptoms contained in the research problem. The representation is done by describing the symptoms as data or facts as they are.

Then, the approach in this research is qualitative research. According to Bodgan and Taylor [5] argues that "Qualitative approach as a research procedure that produces descriptive data in the form of written/spoken words from people or observable behavior". In this case it should not isolate an individual or organization into variables or hypotheses, but it is necessary to view it as part of a whole. The strategy used in this qualitative research is phenomenology. "Phenomenology is chosen because researchers identify a particular phenomenon, and require researchers to study subjects directly involved in developing meaningful patterns and relationships" [6]. 
Data collection techniques that are often used are observation of participation, interviews, and documentation. This research uses data sources orally and in writing so that in this research the data collection techniques carried out are: 1) observation, according to Sugiyono [7], observation is the basis of all science; 2) interview is a conversation with a specific intent. Defining an interview or interview is a meeting of two people to exchange information and ideas through question and answer, so that meaning can be contributed in a particular topic [8]; 3) documentation, includes photographs at the time the researchers went down directly to research, and 4) literature for the completeness of data and information for this research, the research adds data from books, literature studies, scientific papers, articles from the internet, and other sources relevant to research problems.

\section{RESULTS AND DISCUSSION}

\section{Leadership Strategy of the Principal in Improving Teacher Performance at SMK Bakti Ibu 3 Palembang.}

In analyzing this in the beginning by revealing the meaning of the strategy as a way applied by a person in this case the leader to achieve the desired goal. If carefully observed that language, strategy provides understanding as a strategy, tips, tricks, ways. Understanding the performance of teachers at SMK Bakti Ibu 3 Palembang that teacher performance is the maximum ability in carrying out tasks and responsibilities in the learning process, such as planning, implementing and evaluating learning outcomes in order to be realized, teacher performance is an effort or way of working by teachers in the teaching and learning process professionally and quality based on their skills as teachers and educators. As for something that can be achieved by a teacher in carrying out his duties and achieving his goals in teaching and educating.

The statement was made after noting that the leadership carried out by the headmaster has a direction, such as the process of influencing or giving examples of leaders to their followers in an effort to achieve organization goals, then in leading the principal of SMK Bakti Ibu 3 Palembang has the art of influencing and directing people by means of obedience, honor trust, and passionate cooperation in achieving common goals and the ability to influence and inspire and direct the actions of a person or group to achieve the expected goals, although not very perfect, but involves three things namely leaders, followers, and certain situations, thereby the ability to influence a group to achieve goals. This is consistent with the role of the Principal as a leader whose leadership style must be able to influence other people or subordinates who must have good emotional intelligence; and who must have high job satisfaction [9].

2. Constraints on the Implementation of The Principal's Leadership Strategy in Improving Teacher Performance at SMK Bakti Ibu 3 Palembang.

In any management range managed, then it is certain to be in contact with the obstacles in the field in the implementation of leadership strategies, including the leadership of the principal of SMK Bakti Ibu 3 Palembang also does not escape the problems faced, to analyze the formulation of this second problem that in reality the management of the organization has many factors that affect performance, therefore all the performance on the outline is influenced by two things, namely individual factors themselves such as discipline, motivation, skills, and also education and situation factors, such as work climate, salary level, achievement opportunities, and so on. With the proper functioning of leadership management, it is believed that the institutions they lead will experience development and improvement in the quality of education [10].

Based on research conducted at SMK Bakti Ibu 3 Palembang, this school is one of the schools that has several specificities, including; students who are familiar with the majors. The achievements achieved in this school, during the period since its establishment to date have been achieved well, this can be seen from the achievements achieved in the 2019/2020 school year, $90 \%$ have gone well, ranging from the teaching and learning process, curriculum targets, teacher activities, and the activities of the students. Specificity, curriculum, and achievements cannot be easily run and achieved over time. And based on the discussion in this study, the authors conducted a study at SMK Bakti Ibu 3 Palembang on the efforts or strategies carried out by the principal in improving teacher performance. It can be seen from how the teacher works optimization. In this context, the research begins by looking at how their perception of each school's performance, supporting factors, competence, discipline, and the responsibility of teachers in carrying out all educational activities.

In general, all parties, especially teachers in this school, already understand and understand their performance. They can know and understand what to do and what not to do, this is also related to the division of work duties and responsibilities of each party. Thus, good cooperation can be established between each other in accordance with their respective duties. Thus, at SMK Bakti Ibu 3 Palembang, all fulfillment of needs, discipline, potential, and participation of teachers shows that in the implementation of their responsibilities as a teacher shows good performance. This is also supported by various strategies carried out by the headmaster together with the teachers, and the foundation parties. Thus, it can be concluded that the strategy used by the 
headmaster together with the relevant parties in improving teacher performance, shows effective results in implementing and achieving educational objectives.

\section{CONCLUSION}

The headmaster's leadership strategy in improving teacher performance at SMK Bakti Ibu 3 Palembang shows that; The headmaster's leadership strategy in improving teacher performance at SMK Bakti Ibu 3 Palembang by improving discipline by checking the attendance list, providing motivation, being an example by providing the best examples in all actions in school, and supervising, among others, supervision, assessment and evaluation of the performance of teachers and education personnel. The constraints that occur in the leadership strategy of the principal in improving teacher performance at SMK Bakti Ibu 3 Palembang, some teachers do not use teaching devices, exit faster than the time specified by the school, are not motivated in improving their performance, do not respond to the accuracy of the leadership and supervision in SMK Bakti Ibu 3 Palembang is carried out only 1 time a year, the lack of school infrastructure, the supervisors of the development is less instrumental in coaching.

The way the headmaster overcomes obstacles in improving teacher performance at SMK Bakti Ibu 3 Palembang is to improve discipline by providing warnings and reprimands, providing motivation in developing human resources, supervising 1 time in the quarter by involving supervisors, establishing cooperation with related parties.

\section{ACKNOWLEDGMENT}

This research is taken from the final project of the author at the PGRI University graduate program Palembang. Thank you Dr. H. Bukman Lian, MM, M.Si, Dr. Saiful Eddy, M.Si Dr. Happy Fitria, M.Pd . Dr. Edi Harapan, M.Pd and Dr. Rohana, M.Pd for their support and involvement during the writing of this article.

\section{REFERENCES}

[1] Purwanto. (2009). Evaluation of Learning Outcomes. Surakarta: Learning Library

[2] Handoko, T. H. (2011). Human Resources Personnel Management. Yogyakarta: BPFE.

[3] Rifa'i, A \& Anni, C.T. (2012). Educational Psychology. Semarang: UPT UNNES Press.

[4] Shulhan, M. (2013). Leadership Model of Madrasah Head in Improving Teacher Performance. Yokyakarta: Success Offset.
[5] Moleong, L. (2010). Qualitative Research Method. Bandung: PT. Teen Rosda Karya.

[6] Creswell, J. W. (2010). Research design: qualitative, quantitative, and mixed approach. Yogjakarta: PT Pustaka Pelajar.

[7] Sugiyono. (2009). Qualitative and $R \& D$ Qantitative Research Method. Bandung: Afabeta.

[8] Sugiyono. (2012). Quantitative, Qualitative, and $R \& D$. Bandung Approach Education Research Method: Alfabeta.

[9] Asvio, N., Yamin, M., \& Risnita. (2019). Influence of Leadership Style, Emotional Intelligence and Job Satisfaction toward Organizational Commitment (Survey at SMA Muhammadiyah South Sumatera). International Journal of Scientific \& Technology Research 8 (8).

[10] Hendriyadi, Ritonga, A. H., \& Us, K. A. (2020). Management Leadership in Improving the Quality of Graduates of Private Islamic Religious Colleges in Jambi Province. International Journal of Progressive Sciences and Technologies (IJPSAT) Vol. 23 No. 2 November 2020, pp. 42-51 Retrieved from https://ijpsat.ijshtjournals.org/index.php/ijpsat/article/view/2308 